\title{
Detectors and instruments for detection of $X$-ray radiation on the basis of zinc selenide crystals
}

\author{
V.D.Ryzhikov, V.G.Volkov, O.D.Opolonin, \\ S.V.Makhota, V.V.Maksymchuk \\ Institute for Scintillation Materials, STC "Institute for Single Crystals", \\ National Academy of Sciences of Ukraine, 60 Lenin Ave., 61001 Kharkiv, \\ Ukraine
}

Received September 7, 2015

Theoretical analysis and experimental studies have been carried out of parameters of two-layer sandwich-detector of scintillator-photodiode type, in which the low-energy detector works both as absorption filter of low-energy fraction of radiation for the high-energy detector and detector of the low-energy radiation. The energy dependence deviation does not exceed $\pm 5 \%$ in the range from 30 to $120 \mathrm{keV}$. The developed detector and the instrument designed on its base allow contactless measurement of anode voltage of X-ray emitter from 40 to $140 \mathrm{kV}$ with accuracy of $\pm 3 \%$. The dose rate measurement range is 1-200 R/min.

Keywords: X-ray, tester, ZnSe crystal, sendwich-detector, siftware

Проведен теоретический анализ и экспериментальное исследование параметров двухслойного сэндвич-детектора типа сцинтиллятор-фотодиод, в котором низкоэнергетический детектор служит фильтром поглощения низкоэнергетической части излучения для высокоэнергетического детектора и одновременно регистратором низкоэнергетической части спектра. Неравномерность энергетической зависимости не превышает $\pm 5 \%$ в диапазоне от 30 до 120 кэВ. Детектор и прибор на его основе позволяют бесконтактным методом измерять анодное напряжение трубки рентгеновского излучателя от 40 до $140 \mathrm{kB}$ с погрешностью не более $\pm 3 \%$. Диапазон измерения мощности дозы от 1 до $200 \mathrm{P} /$ мин.

Детектори i прилади для ресстрації рентгенівського випромінювання на основі кристалів селениду цинку. В.Д.Рижиков, В.Г.Волков, О.Д.Ополонін, С.В.Махота, В.В.Максимчук.

Проведено теоретичний аналіз та експериментальне дослідження параметрів двошарового сендвіч-детектора типу сцинтилятор-фотодіод, в якому низькоенергетичний детектор (НД) служить фільтром поглинання низькоенергетичної частини випромінювання для високоенергетичного детектора (ВД) і водночас реєстратором низькоенергетичної частини спектра. Нерівномірність енергетичної залежності не перевищує $\pm 5 \%$ в діапазоні від 30 до 120 кеВ. Детектор і прилад на його основі дозволяють безконтактним методом вимірювати анодну напругу трубки рентгенівського випромінювача від 40 до 140 кВ з похибкою не більше $\pm 3 \%$. Діапазон вимірювання потужності дози від 1 до $200 \mathrm{P} / \mathrm{xв}$. 


\section{Introduction}

Scintillators based on zinc selenide crystals [1-3], are characterized by their high light output $(<70000$ photons/MeV) [4], broad $\left(<10^{6}\right)$ dynamic range with practically linear dependence on the dose rate, high radiation stability [5], thermal stability up to $>100^{\circ} \mathrm{C}$, low afterglow level (less than $10 \%$ after $5 \mathrm{~ms}$ ). Their emission spectrum with luminescence maximum close to $640 \mathrm{~nm}$ is well matched with photosensitivity spectrum of silicon photodiodes. Because of these advantages, ZnSe-based scintillators are used in dosimeters for monitoring powerful radiation fluxes $[5,6]$, were proposed for application in computer tomography $[7,8]$ and, in recent years, found wide application in a new generation of X-ray introscopy systems for security and customs inspection of cargo and hand luggage [9].

Among the drawbacks of these scintillators, one can note rather low transparence to intrinsic radiation (about $0.1 \mathrm{~cm}^{-1}$ ), long decay time (from 5 to $50 \mu \mathrm{s}$, depending on the activator) and low (32) effective atomic number. The last drawback makes them suitable mainly for detection of X-ray radiation (recommended detector thickness up to $5 \mathrm{~mm}$ ), but it is transformed to an advantage when they are used in multi-energy systems. Thin plates of these scintillators ensure practically full absorption of the low-energy region (up to $30-40 \mathrm{keV}$ ) and show weak sensitivity to the high-energy region. This provides for high signal-to-noise ratio of structures composed of high- and low-energy detectors.

The use of 2- and 3-layer structures of zinc selenide scintillators with different filters allows leveling the energy dependence and can be recommended for dosimetry applications of these scintillators [10]. For the same purpose, one can use a composite scintillator with density close to biological objects $[11,12]$. In such structures, small-crystalline granules are put inside plastic filler.

The possibility to level the energy dependence in using several scintillators with filters allowed creation of an instrument for monitoring of X-ray radiation parameters and dose obtained by patients during treatment [13]. In this instrument, three detectors based on zinc selenide scintillators are located behind copper filters of different thickness. Each detector is optimized for a specified range of X-ray radiation spectrum of the emitter $[13,14]$. Also, at the detec-

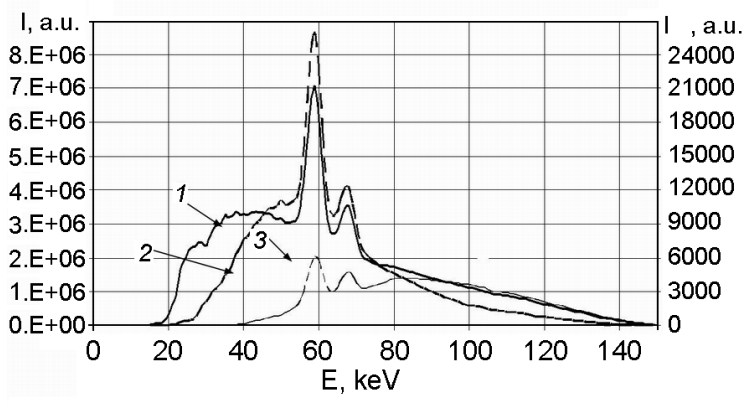

Fig. 1. Energy dependences of detector sensitivity in "sandwich" structures: 1 - X-ray spectrum of W-anode; $2-\mathrm{ZnSe}(\mathrm{Te})$ LED sensitivity $I_{1}, I_{1} / I_{2}=1.32 ; 3-$ sensitivity of $\mathrm{Csl}(\mathrm{TI})$ HED behind ZnSe(Te) LED $I_{3}, I_{3} / I_{4}=$ 2.43 .

tors switch-over boundaries characteristics are deviated from linearity.

Thus, the aim of the present work was creation of a dosimeter-tester of X-ray radiation that would take full advantage of all qualities of zinc selenide scintillators.

\section{Theory}

It is necessary to get estimate density of photons emission flux for to identify dose power of X-ray tube. So it's need to determine it's in limited energy range and to find condition of absorption of photons beam in crystals substance for choose geometry and optimization design detector at whole.

Traditionally used in medicine are emitters with tungsten anode and accelerating voltage up to $140 \mathrm{kV}$. The emission spectrum of W-anode and energy dependences of LED and HED in "sandwich" structures (with different combinations of materials) are shown in Fig. 1.

Since in many cases X-ray emitters are used with filters, we present in Fig. 2 emission spectra for this variant.

Absorption of the photon radiation energy $I_{p h}$ in the crystal is varied as:

$$
I_{p h}=I_{0}\left(1-e^{-\mu L}\right),
$$

where $I_{0}$ is the flux density $I_{p h}$ in the input plane of the crystal, $\mu$ is the linear absorption coefficient of photon radiation determined according to [15].

Spectral radiation density $I_{v}$ for continuous spectrum of $\mathrm{X}$-ray radiation generated at anode current $i$ from the anode made of substance with atomic number $Z$ can be presented, for approximate calculations, as [17]

$$
I_{v}=C i Z\left(v_{0}-v\right) \text {. }
$$




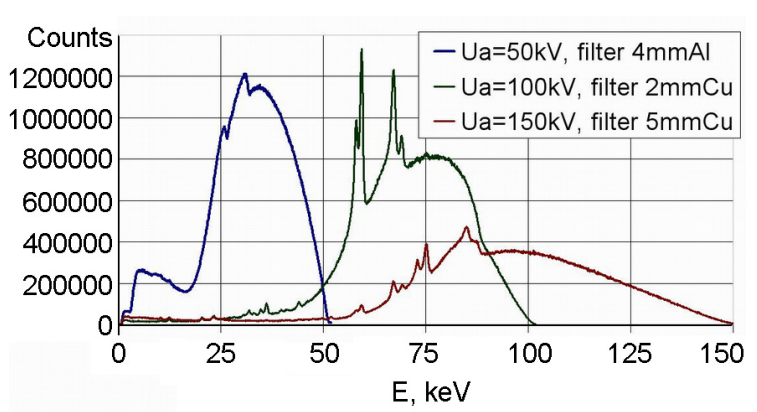

Fig. 2. X-ray radiation spectra obtained at different anode voltages of the $\mathrm{X}$-ray source and at different filtration conditions.

The intensity of X-ray bremsstrahlung generated at voltage $U$ can be found by integration of the expression (2) [11]:

$$
I=\int I_{v} d v=\operatorname{CiZ} \int\left(v-v_{0}\right) d v=C i Z v_{0}^{2} / 2
$$

The signal coming from X-ray detector of scintillator-photodiode type in the form of current is proportional to the intensity of $\mathrm{X}$-ray radiation in the spectral range of the detector sensitivity.

The detector signal can be calculated as integral of radiation spectral density multiplied by spectral sensitivity of the detector.

Within a certain approximation, when characteristics of spectral sensitivity are taken as ideal, the problem of finding lowenergy and high-energy detector signals is reduced to varying the integration limits in (3) and introducing a constant factor $D$ for each specific detector.

To obtain the low-energy detector signal, the integration limits are from 0 to frequency $v_{1}$, leading to the expression

$$
I_{D L}=D_{L} C i Z\left(v_{0} v_{1}-v_{1}^{2} / 2\right) \text {. }
$$

For the high-energy detector, the integration limits are from $v_{1}$ to $v_{0}$ :

$$
I_{D H}=D_{H} C i Z\left(v_{0}-v_{1}\right)^{2} / 2 \text {. }
$$

To calculate the anode voltage of the emitter, expressions (4) and (5) should be used. Accounting for sensitivity of the detectors, the calculation procedure includes calibration coefficients with respect to the radiation dose rate.

In general, the $\mathrm{X}$-ray sensitivity is calculated from the following considerations. Transformation of ionizing radiation energy $E_{\gamma}$ to the initial SELDI signal goes through several stages related to the following processes:
1. Absorption of the initial radiation in the scintillator. The absorbed radiation $a_{\gamma}=$ $\left(\mu_{a} / \mu\left(1-\mathrm{e}^{-\mu} d\right)\right.$, where $\mu$ is the linear absorption coefficient, $\mu_{a}$ is the coefficient corresponding to the real absorption characterizing that fraction of $E_{\gamma}$ that is transferred to the scintillator, and $d$ is the scintillator thickness.

2. Transformation of the absorbed energy into light scintillation $h v \cdot N_{c}=\eta_{S C D} \cdot E_{\gamma}$, where $N_{c}$ is the total number of scintillation photons, $\eta_{S C}$ is the conversion efficiency, or the physical light yield of the scintillator.

3 . Collection of light quanta on the photodiode (PD), the efficiency of which is determined by the light collection coefficient $K_{c}=N_{p h} / N c, N_{p h}$ is the number of light quanta that have reached $\mathrm{PD}$.

4. Transformation of the light energy absorbed by PD to the energy of charge carriers, which is dependent upon quantum efficiency of $\mathrm{PD}$ and spectral matching coefficient $K_{u}$ of luminescence spectrum of the scintillator and spectral sensitivity of PD.

5. Separation at the $p-n$ junction and accumulation of charge carriers at PD electrodes, determined by efficiency of charge carrier collection $\eta_{e}$.

As a result, the output signal $Q$ of the scintielectronic detector (SELDI) is

$Q=\left(a_{\gamma} \cdot e \cdot \frac{E_{\gamma}}{h v}\right) \cdot\left(\eta_{S C} \cdot \eta_{P D} \cdot \eta_{e} \cdot K_{u} \cdot K_{c}\right)$,

and the $\mathrm{X}$-ray sensitivity $C$ is

$$
C=Q / E_{\gamma}[\text { Coulombs } / \mathrm{eV}]
$$

The intensity of X-ray bremsstrahlung can be found by integration of (2). The obtained result shows that the dose rate is linearly dependent upon the anode current, and quadratically dependent on the potential difference of the X-ray tube accelerating field. The dose absorbed by the irradiated object is calculated as integral of dose rate over the total time.

Integrating the expression (2) from 0 to $v_{1}$, we obtain an analytical expression for the low-energy active filter:

$$
I_{D L}=D_{L} C i Z\left(v_{0} v_{1}-v_{1}^{2} / 2\right) \text {. }
$$

Inegrating (2) from $v_{1}$ to $v_{0}$, we find an analytical expression for the HED signal:

$$
I_{D H}=D_{H} C i Z\left(\left(v_{0}-v_{1}\right)^{2} / 2\right) .
$$


Table 1. Thickness of $90 \%$ absorption $\mathrm{L}_{\mathrm{sc}}$ as function of photon radiation flux energy $E_{p h}$

\begin{tabular}{||c|c|c|c|c|c|c|c||}
\hline \hline$E_{p h}, \mathrm{keV}$ & 10 & 20 & 50 & 80 & 100 & 120 & 150 \\
\hline$L_{s c}, \mathrm{~mm}$ & & & & & & & \\
$\mathrm{ZnSe}(\mathrm{Te})$ & 0.03 & 0.1 & 1.2 & 4.4 & 7.5 & 11 & 17 \\
$\mathrm{Csl}(\mathrm{TI})$ & 0.03 & 0.19 & 0.4 & 1.4 & 2.5 & 4.0 & 6.9 \\
$\mathrm{CdWO}_{4}$ & 0.03 & 0.07 & 0.48 & 0.6 & 1.1 & 1.7 & 2.9 \\
\hline \hline
\end{tabular}

The signal (in the form of current) coming from $\mathrm{X}$-ray radiation detector of scintillator-photodiode type is proportional to:

- X-ray radiation intensity in the spectral range of detector sensitivity.

- Area of the detector output window, which should be perpendicular to the flux direction of $\mathrm{X}$-ray radiation.

- The intrinsic sensitivity of the detector, which is determined by its design and material.

The detector signal can be calculated as integral of radiation spectral density multiplied by spectral sensitivity of the detector.

Summing up the results of these rather complex and tedious calculations, it should be noted that the detector current is proportional to $\mathrm{X}$-ray radiation intensity, and spectral dependence of the detector sensitivity is determined by the amplitude of scintillation at photon energy $E_{j}$.

The intensity of photon radiation flux in the output plane for a given crystal thickness was calculated accounting for the absorption coefficient for known crystal transparence. Thus, the optimum scintillator thickness (for a given energy) $L_{o p t}$ is smaller that the thickness of $90 \%$ absorption [16].

Fig. 3 shows this dependence accounting for the difference in light output and spectral matching of these scintillators with photodiode [16].

A generally accepted criterion for choosing the detecting element thickness $L_{s c}$ is $90 \%$ absorption of the energy flux of the photon ionizing radiation $E_{p h}$ in the scintillator material. In Table $1, L_{s c}$ values for some scintillators are presented. Calculations were carried out according to [15].

\section{Experimental}

In this work, for measurements of X-ray radiation dose rate and parameters of the emitter (anode voltage and X-ray tube current) we used two-layer sandwich detectors of scintillator-photodiode type.

There were investigation of energy-selection probability detectors type SC-PD for

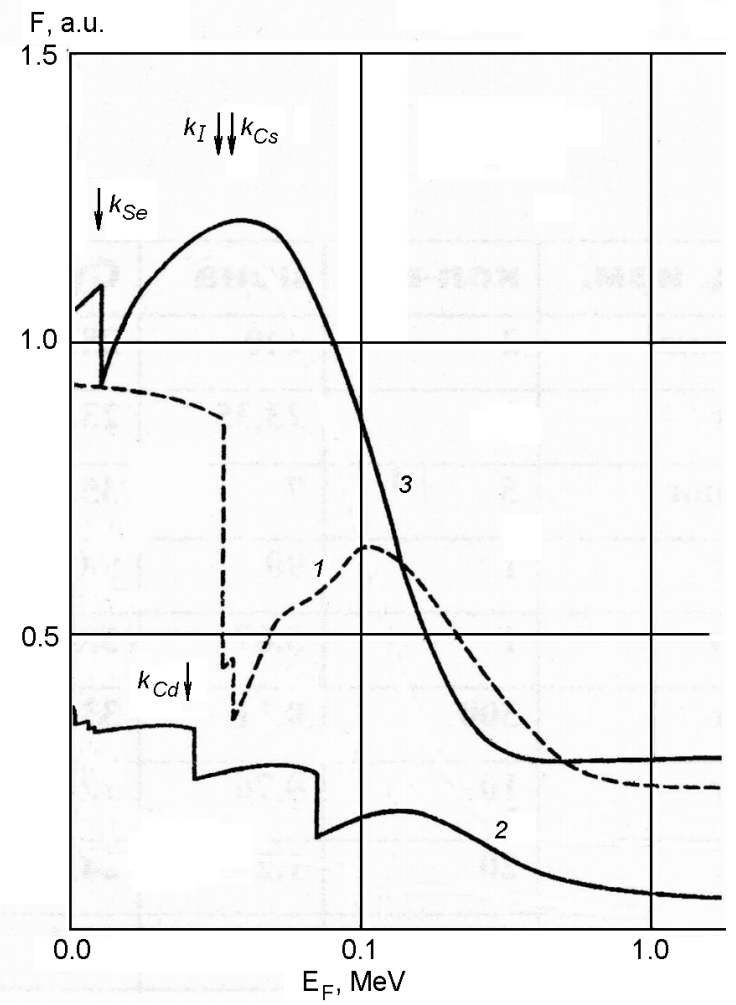

Fig. 3. Dependence of intensity luminescence (with spectral according with photoreciver) for optimum thickness crystals from energy photons beam. $1-\mathrm{Csl}(\mathrm{TI}), 2-\mathrm{CWO}, 3-\mathrm{ZnSe}$ $\left(K_{a b s}=0.2 \mathrm{~cm}^{-1}\right)$. Arrays mark energy of $\mathrm{K}$ abrupt absorption different elements [16].

example standard couple detectors from double-energy digital radiography system (DRS) and so as three similary detectors with different filter. We choose these objects because similar calculation permit us not only estimate energy-selection parameters of detectors but so as relation signal detectors by used creation without contact measurement anode voltage of X-ray tube.

There were measured at first outside spectrum of X-ray beam with different anode voltage. Further by used base date $\mu_{m}(E)$ and output spectrum X-ray emission it was calculate spectrum X-ray beam that put on scintillator after pass trough filter. All calculation was implement for $\mathrm{ZnSe}(\mathrm{Te})$ 


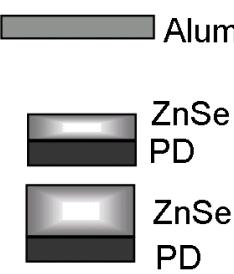

b)

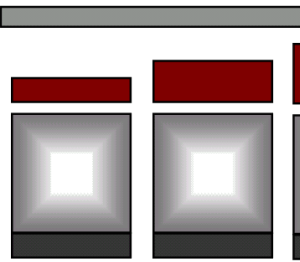

Aluminum

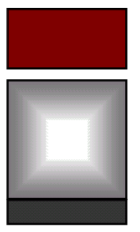

Copper

ZnSe

PD

Fig. 4. Scheme dual-energy detector (a) and three energy-selection detectors with passive filters (b).

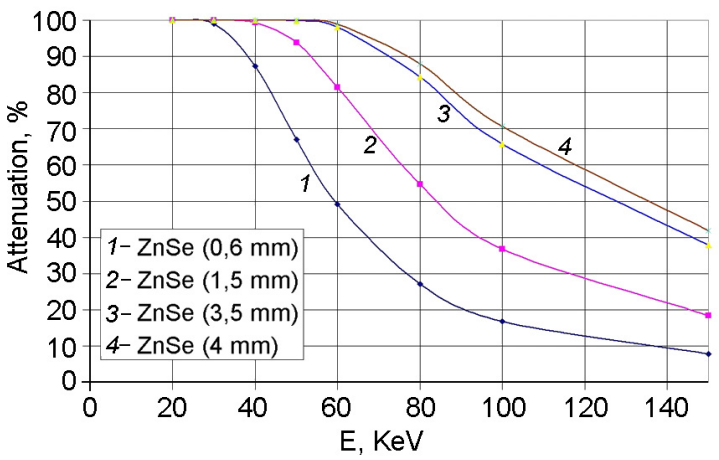

Fig. 5. Energy dependences of X-ray radiation absorption efficiency by zinc selenide of different thickness.

and $\mathrm{Csl}(\mathrm{TI})$ scintillators. For estimate level signals from detectors used value $\mu_{a}(E)$ [15] and $\mu_{e n}(E)$ [15] that according part of energy input beam that pass to charge particle (preferable electrons-photoeffect) in SC. After that calculated spectrum beam output from detectors. At double-energy detectors this spectrum used as spectrum beam input at second (high energy) detectors - HED, that set-top after first - LED detectors (Fig. 4).

Scheme of detectors according Fig. $4 \mathrm{~b}$ by used at device UKREH, Moscow [14]. Scheme of detectors according Fig. 4a. at first proposed at this work for create original device at ISMA NAS of Ukraine, Kharkiv [18].

A traditional solution for leveling the energy dependence of the detector in the X-ray radiation range $30-140 \mathrm{keV}$ is the use of copper filters of different thickness. A unique feature of zinc selenide crystals is that their effective atomic number $(Z=31)$ is the same as atomic number of copper. But, unlike copper, $\mathrm{ZnSe}$ as filter is not passive, but active. A certain fraction of the energy absorbed in low-energy X-ray range $(20-60 \mathrm{keV})$ is transformed to light. Photons of higher energies penetrate through the filter and are detected by the high-energy detector (HED). Thickness of zinc selenide HED should be by an order of magnitude larger to ensure efficient detection. When cesium iodide is used as HED,

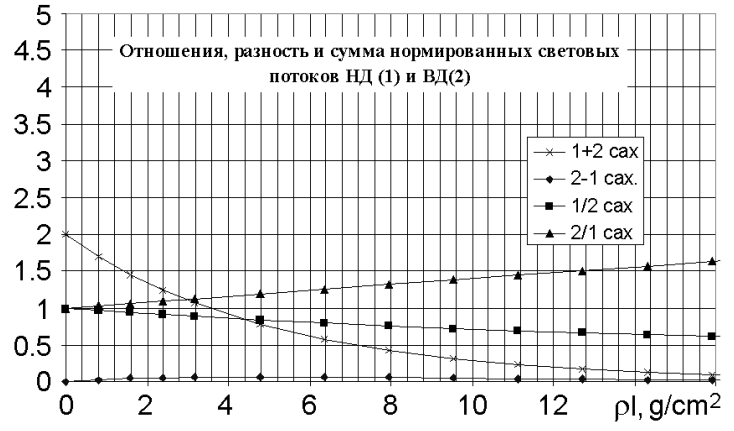

Fig. 6. Ratio, difference and sum of normalized light fluxes LED (1) and HED (2) for sugar.

which has much higher effective atomic number $(Z=54)$, its thickness must be calculated appropriately (Table 1 ).

Traditionally used in medicine are emitters with tungsten anode and accelerating voltage up to $140 \mathrm{kV}$. The emission spectrum of W-anode and energy dependences of LED and HED in "sandwich" structures (with different combinations of materials) are shown in Fig. 1.

Since in many cases X-ray emiters are used with filters, we present in Fig. 2 emission spectra for this variant. Fig. 5 shows the energy dependence of the efficiency of absorption of radiation LED and HED detectors. The use of active filters (LED) in combination with HED opens broad possibilities for application of such sandwich structures. In particular, it becomes possible to analyze and process the sum, difference and ratio of signals coming from these detectors, which ensures broad (up to $10^{6}$ ) measurement range of $\mathrm{X}$-ray radiation intensity from the source and leveling of the energy dependence.

In Fig. 6, we present sensitivity after transmission of radiation through an organic object and in Fig. 7 - the total output signal of HED and LED in different combinations. Signal from detectors that calculated for anode voltage from $30 \mathrm{keV}$ to $150 \mathrm{keV}$ get possibility to get estimate relation signals for dual-energy detector (Fig. 7). As you can see from Fig. 7 relation signals for 


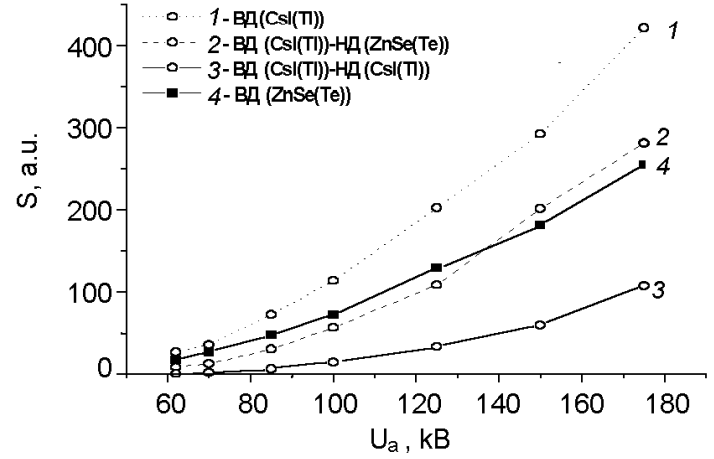

Fig. 7. HED output signal with active filters in different combinations for different tube voltages.

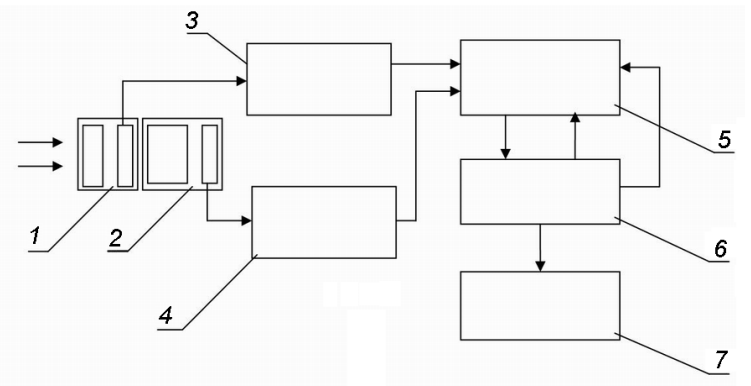

Fig. 9. Schematic design of the instrument "KRISTALL": 1 - detector No.1; 2 - detector No.2; 3 - amplifier No.1; 4 - amplifier No.2; 5 - ADC; 6 - microcontroller; 7 computer.

analasised dual-energy detector enough high that permit us to receive accuracy precision amplitude emission of anode voltage up to $150 \mathrm{keV}$ without transfer switch on/off range measurement.

Experimental measurement of anode voltage by used dual-energy detectors confirm calculation results.

As a result, we have chosen an optimum design of the detector as a whole and geometrical dimensions of LED and HED that allow leveling of the energy dependence to within specified limits (Fig. 8).

Also, we have realized an instrument design for detection of radiation dose rate and parameters of the whole emitter (Fig. 9, 10) [18].

Main technical characteristics of the instrument are presented in Table 2.

The instrument has successfully passes clinical testing and was recommended for general application for X-ray diagnostics in medical institutions.

\section{Conclusions}

An original [18] two-layer sandwich detector of scintillator-photodiode type has been

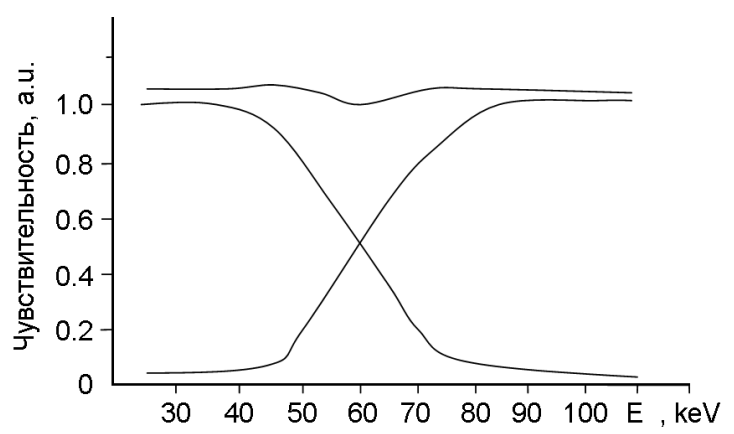

Fig. 8. Energy dependence of sensitivity of LED 1 (curve $a$ ), HED (curve $b$ ) and the total sensitivity of the system (curve 3 ).
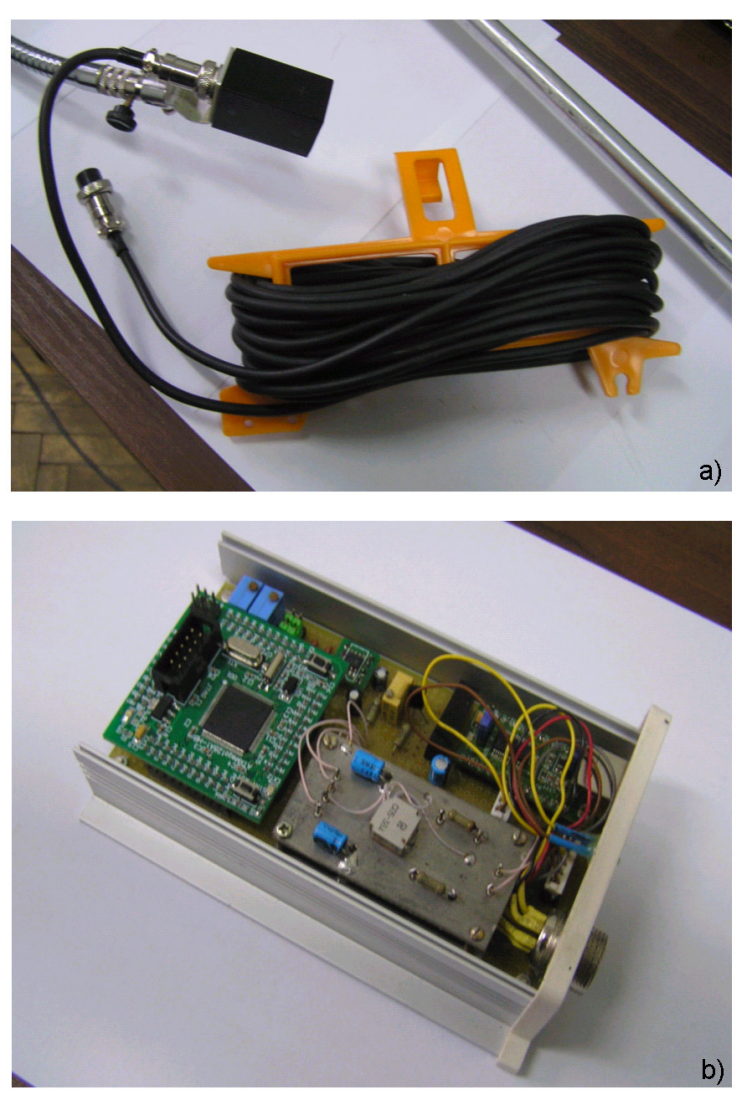

Fig. 10. Blocks of the "Kristall" instrument: a) detection block with connection cable of $10 \mathrm{~m}$ length; b) microprocessor block with open lid.

developed on the basis of exclusive zinc selenide crystals [2, 3], as well as an instrument based thereon for high-precision measurement of radiation dose rate and parameters of the emitter in a broad range (Fig. 10). The instrument has passed clinical testing and was recommended for use in medical institutions for X-ray diagnostics. 
Table 2. Main technical characteristis of the instrument

\begin{tabular}{|c|c|c|c|c|}
\hline Exposition dose rate of $\mathrm{X}$-ray radiation, $\mathrm{R} / \mathrm{min}$ & $\begin{array}{l}\text { From } 1 \\
\text { to } 6\end{array}$ & $\begin{array}{l}\text { From } 6 \\
\text { to } 20\end{array}$ & $\begin{array}{l}\text { From } 20 \\
\text { to } 100 \\
\end{array}$ & $\begin{array}{l}\text { From } 100 \\
\text { to } 200\end{array}$ \\
\hline Basic measurement error, not more than, \% & 20 & 15 & 10 & 10 \\
\hline Variation range of anode voltage, $\mathrm{kV}$ & $\begin{array}{l}\text { From } 30 \\
\text { to } 39\end{array}$ & $\begin{array}{l}\text { From } 40 \\
\text { to } 49\end{array}$ & $\begin{array}{l}\text { From } 50 \\
\quad \text { to } 69\end{array}$ & $\begin{array}{c}\text { From } 70 \\
\text { to } 140\end{array}$ \\
\hline Basic measurement error, not more than, \% & 5 & 3 & 1 & 2.5 \\
\hline Irradiation time range & \multicolumn{4}{|c|}{ From $20 \mathrm{~ms}$ to $3 \mathrm{~min}$} \\
\hline Basic measurement error,. not more than, $\%$ & \multicolumn{4}{|c|}{1} \\
\hline \multicolumn{5}{|c|}{ Testing was carried out under normal conditions according to GOST 27451-87 } \\
\hline Temperature, ${ }^{\circ} \mathrm{C}$ & \multicolumn{4}{|c|}{$20 \pm 2$} \\
\hline Atmospheric pressure, $\mathrm{kPa}$ & \multicolumn{4}{|c|}{$101.3^{+5.4-15.3}$} \\
\hline Relative humidity, \% & \multicolumn{4}{|c|}{$60^{+20}-30$} \\
\hline $\begin{array}{l}\text { All measurements were carried out } \\
\text { after stabilization of the operation regime }\end{array}$ & \multicolumn{4}{|c|}{ Stabilization time of operation regime $-1 \mathrm{~min}$} \\
\hline
\end{tabular}

\section{References}

1. V.D.Ryzhikov, E.F.Chaikovski, Izvestiya $A N$ SSSR, ser. Fizika, 43, 1150 (1979).

2. Ukraine Patent No. 16669 (1997).

3. Ukraine Patent No. 51766 (2002).

4. L.P.Gal'chinetskii, K.A.Katrunov, V.D.Ryzhikov, Pribory $i$ Tekhnika Eksperimenta, No.1, 88 (1991).

5. V.D.Ryzhikov, B.Grinyov, S.Galkin et al., J. Cryst. Growth, 364, 111 (2013).

6. V.D.Ryzhikov, Ya.A.Yakovlev, Atom. Energy, 49, 392 (1990).

7. B. Grinyov, V.D.Ryzhikov, V.P.Seminozhenko, Scintillation Detectors and System of Radiation Monitoring on their Base, Akademperiodika, Kyiv (2010) [in Russian].

8. V.D.Ryzhikov, O.S.Shapiro, S.N.Ignatov, V.I.Silin, Pribory $i$ Tekhnika Eksperimenta, No.4, 155 (1986).

9. USA Patent No. 6.533.092 B1 (2003).

10. USA Patent No. 6445765 B1 (2002).
11. V.D.Ryzhikov, V.P.Sokhin, E.A.Danshin, Pribory $i$ Tekhnika Eksperimenta, No.5, 67 (1990).

12. V.D.Ryzhikov, O.P.Verbitskiy, V.V.Biteman, V.G.Senchishin, USSR author's certificate No. 4706071 (1997).

13. N.N.Blinov, V.A.Kostylev, B.Ya.Narkevich, Physical Foundations of X-ray Diagnostics, AMF-Press, Moscow (2002) [in Russian].

14. N.Blinov, T.Vladimirov, A.Danilenko et al., USSR author's certificate No. 1536525 A1 (1990).

15. O.F.Nemets, Yu.V.Gofman, Handbook on Nuclear Physics, Naukova Dumka, Kiev (1975) [in Russian].

16. V.D.Ryzhikov, V.P.Sokhin, Pribory $i$ Tekhnika Eksperimenta, No.5, 177 (1988).

17. V.V.Klyuev, F.R.Sosnin, V.Aerts et al., e. by V.V.Klyuev, Handbook, v.1, Mashinostroenie, Moscow (1992) [in Russian].

18. Ukraine Patent No a201406346 (2014). 